\title{
Estimation of the density of Buccinum undatum (Gastropoda) off Douglas, Isle of Man
}

\author{
A. E. Kideys \\ Port Erin Marine Laboratory, University of Liverpool; Isle of Man, United Kingdom \\ and \\ Institute of Marine Sciences, Middle East Technical University; P. O. Box 28, 33731, \\ Erdemli, Icel, Turkey
}

\begin{abstract}
The density of the common whelk (Buccinum undatum L.) off Douglas, Isle of Man, was determined by four methods: (1) pot sampling, (2) diving, (3) mark-recapture experiment, and (4) underwater television. Although the values obtained by these methods were comparable, the last two methods yielded overestimations of Buccinum density. The results from diving survey and from pot sampling showed a good agreement, indicating that pot sampling can be used to determine the density of the common whelk, provided a good estimate of the pot attraction area is available. The range of whelk density between February 1989 and August 1990 resulting from pot sampling was between 0.08 and 0.38 individuals $\mathrm{m}^{-2}$. The temporal fluctuations of the whelk densities are discussed in detail.
\end{abstract}

\section{INTRODUCTION}

The common whelk Buccinum undatum $\mathrm{L}$. is a potential fishery resource in Manx waters. Determination of population density and spatial location of the resource is of great importance regarding the development of a new fishery for this species. There are, however, methodological difficulties in estimating the density of active benthic animals such as Buccinum, which occur mostly at depths too great for direct observation.

Pots have generally been used for fishing common whelks (Hancock, 1963; Santarelli \& Gros, 1985; Gros \& Santarelli, 1986; Himmelman, 1988; Kideys \& Hartnoll, 1991) and other whelks (MacIntosh, 1980; Ito et al., 1981; Ito \& Tachizawa, 1981; Davis \& Sisson, 1988). However, the reliability of this method for population density studies should be taken into consideration and, if necessary, tested. Miller (1975) pointed out that catches in traps may provide relative densities, but calculation of absolute densities requires knowledge of the area fished by the trap. Although there are some studies on areas fished by pots for $B$. undatum (Gros \& Santarelli, 1986, off the Channel Isles; Himmelman, 1988, in the Gulf of St Lawrence) and for other whelks (Ito \& Tachizawa, 1981, and Ito et al., 1981, in Lagoon Kuren-Ho; Davis \& Sisson, 1988, in Nantucket Sound, Massachusetts), the importance of the differences in ambient conditions (such as currents, seawater temperature etc.) and in the biology of the whelks studied in each region has been 
emphasized. Therefore, any information on density (or population size) of $B$. undatum based on pot sampling needs verification by other methods.

The importance of mark-recapture experiments in population size or density studies of finfishes is well established (Jones, 1976). This method has been used to estimate growth and mortality rates of bivalves (see Murphy, 1986, for a review) and gastropod molluscs (Hancock, 1963; Forster, 1967; Sire, 1984; Kraeuter et al., 1989). It has also been utilized for the determination of the rate of movement and behaviour of gastropods towards a baited trap (Ito et al., 1980, 1981; Himmelman, 1988). However, there have been very few attempts to determine the population density of gastropods using the mark-recapture method (Hancock, 1963; Ito \& Tachizawa, 1981).

Trawling and dredging as methods of benthic research have always been approached cautiously in quantitative studies (Miller, 1975). However, subtidal studies carried out by direct censusing using underwater television, photography and SCUBA (Self-Contained Underwater Breathing Apparatus) diving have significantly increased in recent years, in particular, parallel to the development of underwater technology and diving techniques (Machan \& Fedra, 1975; Holme \& Barrett, 1977; Chapman et al. 1977; Franklin et al., 1980; Mason et al., 1982; Bergstrom et al., 1987; Davis \& Sisson, 1988; Peck et al., 1990). Censusing whelks using SCUBA diving is probably one of the easiest of these methods although there are certain logistical problems; namely depth (maximum safe depth, breathing compressed air, is $50 \mathrm{~m}$ ), time, efficiency (at a depth of $30 \mathrm{~m}$, a pair of divers can stay down safely for only 20 min twice a day), as well as problems of cold, currents and visibility.

The aim of this study was to estimate the population density of common whelk off Douglas, together with the determination of effective methods.

\section{MATERIAL AND METHODS}

The estimation of the density of Buccinum undatum off Douglas was attempted using several methods: pot fishing, mark-recapture experiments, direct census using underwater television, and diving.

\section{Pot sampling}

Pot sampling was carried out using two strings of seven pots each. However, one pot from each set was lost during the course of study. Therefore, it was necessary to record the number of pots used in each sampling (see Table 1). The distance between each pot on a string was approximately $10 \mathrm{~m}$. Design of the pots was identical to that used for fishing common whelk in French coastal waters. The whelk pots consisted of $40 \times 25 \times 25 \mathrm{~cm}$ high rectangular or cylindrical 5-gallon plastic drums with the top removed. These were weighted down by a cement layer (ca $15 \mathrm{~kg}$ ) at the bottom of each drum, and holes (11 mm diameter) were drilled through the sides to allow diffusion of the bait's smell into the surrounding water. Whelks entered the pots by crawling up the sides and falling through a circular opening, with a net tunnel on top.

Pot sampling was carried out at monthly intervals (February 1989-August 1990 inclusively, except February and July 1990), normally using two sets of pots at the positions shown in Figure 1. Each set was normally left on the sea bed for approximately $24 \mathrm{~h}$. However, bad weather or other commitments for R. V. Cuma meant some fishing 
Table 1. Catch data of Buccinum undatum using pots from February 1989 to August 1990

\begin{tabular}{|c|c|c|c|}
\hline Date & Fishing period (d) & No. of pots & Catch/pot \\
\hline \multicolumn{4}{|l|}{1989} \\
\hline 21/26 Feb.* & $1 / 4$ & 14 & 86.9 \\
\hline 1 Mar. & 3 & 7 & 91.3 \\
\hline $7 \mathrm{Mar}$ & 3 & 7 & 104.6 \\
\hline 19 Apr. & 1 & 7 & 30.4 \\
\hline $25 \mathrm{Apr}$ & 7 & 7 & 47.0 \\
\hline 28 Apr. & 3 & 7 & 58.1 \\
\hline 18 May & 1 & 7 & 86.1 \\
\hline 19 May & 2 & 7 & 77.6 \\
\hline 6 Jun." & 1 & 14 & 52.8 \\
\hline 27 Jun. & 2 & 7 & 42.1 \\
\hline 29 Jun. & 2 & 7 & 44.6 \\
\hline $26 \mathrm{Jul}$. & 1 & 7 & 48.3 \\
\hline $26 \mathrm{Jul}$. & 1 & 7 & 42.3 \\
\hline 28 Aug. & 5 & 6 & 33.8 \\
\hline 31 Aug. & 2 & 6 & 6.8 \\
\hline 28 Sep. & 2 & 7 & 45.6 \\
\hline 28 Sep. & 2 & 6 & 23.8 \\
\hline 13 Oct. & 1 & 6 & 59.5 \\
\hline 13 Oct. & 1. & 7 & 78.9 \\
\hline 24 Nov. & 1 & 6 & 59.5 \\
\hline 24 Nov. & 1 & 7 & 57.1 \\
\hline 12 Dec. & 4 & 6 & 90.0 \\
\hline 12 Dec. & 4 & 7 & 86.6 \\
\hline \multicolumn{4}{|l|}{1990} \\
\hline 8 Jan. & 1 & 6 & 40.5 \\
\hline 8 Jan. & 1 & 7 & 66.0 \\
\hline 12 Маг.* & 5 & 7 & 7.6 \\
\hline 12 Mar."* & 5 & 6 & 14.0 \\
\hline $10 \mathrm{Apr}$ & 1 & 7 & 20.3 \\
\hline 10 Apr. & 1 & 6 & 26.7 \\
\hline 1 May & 1 & 6 & 22.8 \\
\hline 1 May & 3 & 6 & 47.6 \\
\hline 1 Jun. & 2 & 6 & 36.7 \\
\hline $1 \mathrm{Jun}$. & 2 & 6 & 54.3 \\
\hline 1 Aug. & 1 & 6 & 19.5 \\
\hline $\begin{array}{l}\text { Two sets of } p \\
\text { Small amoun }\end{array}$ & $\begin{array}{l}\text { ed } \\
\text { ed }\end{array}$ & & \\
\hline
\end{tabular}

periods were longer. The fishing period, i.e. the time pots were left on the sea bed at each sampling, was also recorded. Pots were generally left 1-2 days in the sea, maximum sampling period being 7 days.

Usually, excessive amounts of dead dogfish (Scyliorhinus canicula), scallops (Pecten maximus and Chlamys sp.), squid (Loligo forbesi) and very rarely herring (Clupea harengus) or other fishes were utilized as bait during the fishing for $B$. undatum. It has 


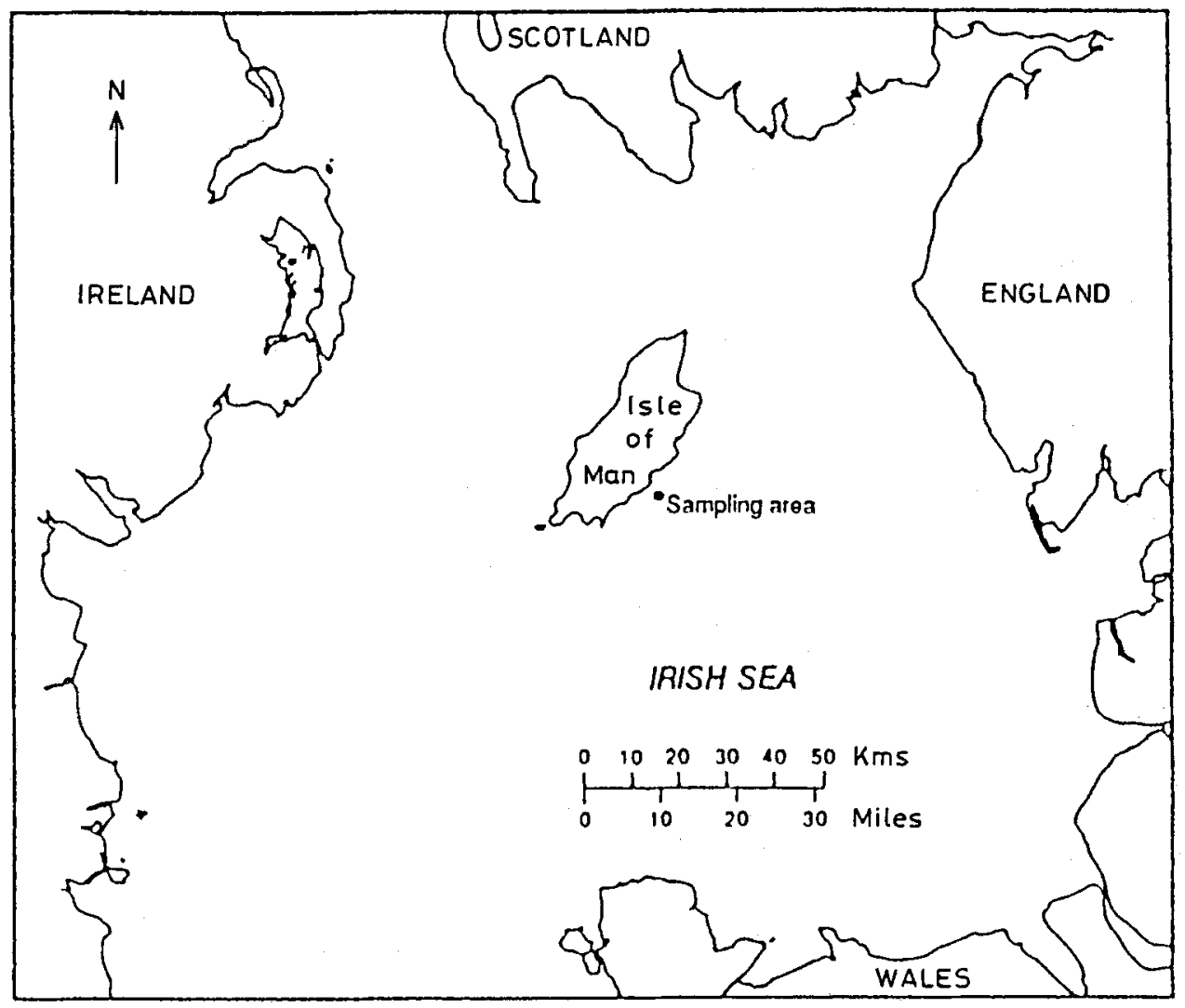

Fig. 1. Study area

been observed that in laboratory experiments dogfish and scallop offal were preferred by whelks to herring and plaice (Pleuronectes platessa) (C. J. Gilling, pers. comm., Port Erin Marine Laboratory, Isle of Man). The advantages of these two preferred baits were that in summer dogfish is often an unwelcome trash fish in trawl catches, and in winter scallop offal is often readily available.

\section{Mark-recapture experiment}

Animals collected in April 1989 by pots from the sampling area were used for markrecapture experiment.

The whelks were tagged as soon as they arrived at the laboratory. A total of 233 animals were tagged. The details of the tagging are given elsewhere (cf. Kideys, 1991). After the tagging, the animals were also marked with a fluorescent marker (oxytetracycline) to estimate their growth rate (see Kideys, 1991). They were held, until release, in larger (ca $140 \times 50 \mathrm{~cm}$ rectangular) tanks provided with aerated, flowing seawater. During this period, the whelks were fed at three-day intervals with scallops (Pecten 
maximus and Chlamys opercularis). There were no deaths prior to release. They were released in May 1989 to a single position in the sampling area.

The pots were utilized to recapture tagged individuals. Other methods such as diving and dredging were tried out to recapture tagged animals; however, none of them was successful. The length, weight, and position of the recaptured animals were recorded along with data on the other individuals caught.

\section{Underwater television survey}

An underwater television survey was carried out on 13th September 1990. The field of vision of the television camera was approximately $1 \mathrm{~m}^{2}$.

The equipment consisted of a remote controlled television camera (MiniRover ${ }^{\mathrm{TM}}$ ) and necessary light sources mounted on a sledge. Details of this equipment are given elsewhere (Kideys, 1991).

The MiniRover was towed over a three-hour period from $11.00 \mathrm{~h}$ to $14.00 \mathrm{~h}$. Sea conditions (i.e. slack water, calm sea) were ideal during this work. The videotape was carefully analysed in the laboratory to count individual $B$. undatum. However, the existence of Glycymeris and other dead shell material made the counting of Buccinum difficult, probably leading to some misidentification.

\section{Diving survey}

An attempt was also made to census the $B$. undatum population in the study area using SCUBA diving techniques. The counting bar used for these observations was designed and constructed by U. Wilson (Port Erin Marine Laboratory, Isle of Man) from a four meter length of plastic piping (diameter $4 \mathrm{~cm}$ ). In the centre, there was a reel with $50 \mathrm{~m}$ of line marked at $10-\mathrm{m}$ intervals. Each diver took up position, with a recording board, on either side and was therefore able to monitor an area of $50 \mathrm{~m} \times 2 \mathrm{~m}$. The line was clipped to a sinker weight to provide a starting point. The survey line was along a compass bearing, usually using tidal currents where possible. The divers recorded all common whelks in their sampling area on the recording board. At the end of $50 \mathrm{~m}$, the line locked and divers sent the bar up on an inflatable buoy before proceeding with their own ascent.

This survey was carried out on 1st June 1990. Initially, it was planned to survey with five pairs of divers. However, only two pairs of divers were able to complete the task.

\section{RESULTS}

\section{Estimation of density from pot sampling}

The pots used for sampling appeared to work very well. The cement bottom layer of the pots always kept them in an upright position. This was verified when one pot which had been lost for approximately six months was seen in an upright position during the underwater television survey. This is an important factor as it prevents escape of the animals from the trap. There were no field observations on the efficiency of pots for retaining whelks, but an inability of whelks to escape the pots was observed several times 




Fig. 2. Densities of Buccinum undatum in an area off Douglas according to pot sampling carried out throughout sampling period

in the laboratory. Animals trying to escape fell down to the bottom from the fringe of the netting at the top of pots. Only the animals with a maximum dimension of less than $11 \mathrm{~mm}$ were able to escape from the pots through the holes on the wall of the pot.

Pots were never observed completely full, so there did not appear to be gear saturation. A few other species (such as hermit crab Eupagurus bernhardus; common topshell Calliostoma zizyphinum; red whelk Neptunea antiqua and Colus gracilis) in very low numbers were found to compete for the bait in the pots.

The numbers of animals caught $\left(\right.$ pot $^{-1}$ ) for each sampling are given in Table 1. The range of the catch values was comparable (being 104.6 individuals on 7th March 1989 to 6.8 individuals on 31st August 1990). Mean monthly catch per pot was observed to be highest in March 1989 with a value of 98 individuals, and lowest in August 1989 with a value of 19.5 individuals (excluding March 1990 where only a small amount of bait was available for sampling). The next lowest value was observed in August 1990. The number of individuals caught per pot was lower in the sampling months of 1990 in comparison to the respective months of 1989 , which may suggest a decrease in the population of the whelks.

A pot was assumed to attract animals from $373 \mathrm{~m}^{2}$ (from Gros \& Santarelli, 1986, for the same species in Channel Islands region). This gave a gathering area of $1693 \mathrm{~m}^{2}$ for seven pots and $1473 \mathrm{~m}^{2}$ for six pots, respectively.

The estimated density of Buccinum from pot fishing was 0.36 individuals $\mathrm{m}^{-2}$ in February 1989 (at the start of sampling) and decreased to 0.08 individuals $\mathrm{m}^{-2}$ in August 1990 (at the termination of sampling) (Fig. 2). The highest density for the sampling period was obtained in March 1989 (0.40 individuals $\mathrm{m}^{-2}$ ). There did not appear to be a 
systematic change in catches as there was no significant correlation between the density values of same months of 1989 and 1990 (Spearman's rank correlation, $r_{s}=-0.1 ; n=5$; $\mathrm{p}<0.05$ ).

\section{Estimation of density from mark-recapture experiments}

Only 13 individuals from a total of 233 tagged individuals were recaptured by pots during more than 16 months sampling period. The majority of the returns occurred in June 1989, one month after release.

The area referred to for the density estimation of whelks was determined as follows. The greatest distance between released animals and captured animals was assumed to be the radius for the reference area. This gives an area of $80384 \mathrm{~m}^{2}$. The number of whelks for this reference area was calculated using the equation

$$
\mathrm{N}=(\mathrm{M} \times \mathrm{C} / \mathrm{R})(\text { Ricker, 1975) }
$$

where $\mathrm{N}$ is the size of population at time of marking, $\mathrm{M}$ is the number of fish marked, $\mathrm{C}$ is the catch or sample taken for consensus, and $\mathrm{R}$ is the number of recaptured marks in the sample. The total number of animals in the area ranged from 39202 in June 1989 to 156026 in January 1990 which gives density estimates from 0.49 to 1.94 individuals $\mathrm{m}^{-2}$ over these months (Table 2).

\section{Estimation of density from underwater television survey}

After three hours underwater television survey in the study area, the video tape was carefully analysed, in the laboratory, for whelks. In general, the study area was a uniform habitat with occasional aggregations of shell material, probably caused by wave motion. The other recognizable fauna included starfish (Asterias rubens), queen scallop (Chlamys opercularis), hermit crab (Eupagurus sp.), sea urchin (Echinus esculaentus), hydrozoans, octopus, and flatfish. The smallest individual of Buccinum was measured on the screen as approximately $60 \mathrm{~mm}$ in shell length. A total of 1200 whelks were counted in the surveyed area. The total area covered was calculated from ship's speed, time of surveying and width of the viewed area. This gave a survey area of approximately $3600 \mathrm{~m}^{2}$. The numbers of whelks counted in the first, second and third $1200 \mathrm{~m}^{2}$ were 428 $\left(0.36\right.$ individuals $\left.\mathrm{m}^{-2}\right), 432\left(0.36\right.$ individuals $\left.\mathrm{m}^{-2}\right)$ and $340\left(0.28\right.$ individuals $\left.\mathrm{m}^{-2}\right)$, respectively. This gives a mean of $0.33 \pm 0.05$ individuals $\mathrm{m}^{-2}$ for animals larger than $60 \mathrm{~mm}$ in September 1990.

\section{Estimation of density from diving survey}

Only two pairs of the preplanned five pairs of divers were able to count the whelks in the specified area because of worsening sea conditions and particularly strong tidal currents during the survey.

The numbers of Buccinum undatum counted from a direct census by these four divers are given in Table 3 , together with estimates of density. There was a substantial difference (range 0.03-0.36 individuals $\mathrm{m}^{-2}$ ) between the four estimates (Table 3 ). A value of 0.36 individuals $\mathrm{m}^{-2}$ was counted by myself and this gave a density of 0.36 individuals $\mathrm{m}^{-2}$ for this species in the study area in June 1990. The mean from the census results of four divers was $0.17 \pm 0.24$ individuals $\mathrm{m}^{-2}$. 
Table 2. The monthly densities of Buccinum undatum off Douglas, from mark-recapture experiment (233 whelks). The numbers of animals (N) was referred to an area of $80384 \mathrm{~m}^{2}$ to find density values. See text for the calculation of $\mathrm{N}$

\begin{tabular}{|c|c|c|c|c|}
\hline Month & Catch & Recapture & $\mathrm{N}$ & Density (N. $\mathrm{m}^{-2}$ ) \\
\hline \multicolumn{5}{|l|}{1989} \\
\hline June & 1346 & 8 & 39202 & 0.49 \\
\hline July & 635 & 0 & $?$ & $?$ \\
\hline August & 203 & 0 & $?$ & $?$ \\
\hline September & 706 & 2 & 79425 & 0.99 \\
\hline October & 909 & 2 & 101353 & 1.26 \\
\hline November & 753 & 0 & $?$ & $?$ \\
\hline December & 1144 & 0 & $?$ & $?$ \\
\hline \multicolumn{5}{|l|}{1990} \\
\hline January & 706 & 1 & 156026 & 1.94 \\
\hline March & 136 & 0 & $?$ & $?$ \\
\hline April & 302 & 0 & $?$ & $?$ \\
\hline May & 470 & 1 & 103400 & 1.29 \\
\hline June & 545 & 0 & $?$ & $?$ \\
\hline August & 117 & 0 & $?$ & $?$ \\
\hline December & 117 & 1 & 92199 & 1.15 \\
\hline
\end{tabular}

Table 3. Direct census results of Buccinum undatum off Douglas, from diving survey on the $1^{\text {st }}$ of June 1990. (The other three pairs of divers were not able to dive because of unsuitable sea conditions). A.E.K. = Ahmet E. Kideys

\begin{tabular}{|lcc|}
\hline Diver & Count (ind. $200 \mathrm{~m}^{-2}$ ) & Density (ind. $\mathrm{m}^{-2}$ ) \\
\hline 1A (A.E.K.) & 72 & 0.36 \\
1B & 46 & 0.23 \\
2A & 12 & 0.06 \\
2B & 6 & 0.03 \\
Mean & $34 \pm 31$ & $0.17 \pm 0.15$ \\
\hline
\end{tabular}

\section{DISCUSSION}

Studies on the population dynamics of benthic fish stocks have drawn attention to the need to consider the relationship between pot immersion time and catch (Bennett, 1974). The effect of pot immersion time on catches of shellfish has been reported (Bennett \& Brown, 1979; Skud, 1979). This effect of variable fishing time, however, providing the pots are immersed for long enough, may be immaterial for various shellfish, including whelks. For example, Kennelly (1989), using very short-term experiments, observed that while significantly more spanner crabs (Ranina ranina) were caught after 60 min and 120 min than after $15 \mathrm{~min}$, there was no significant difference between traps left for $60 \mathrm{~min}$ and $120 \mathrm{~min}$. Similarly, Bennett \& Lovewell (1977), using pots, found that the catch-per- 
unit-effort (cpue) for periods of immersion between 1-5 days was almost constant for lobster (Homarus gammarus). Davis \& Sisson (1988) also reported that catches of channeled whelks, Busycotypus canaliculatus, after forty-eight hours, were not significantly greater than those after twenty-four hours. In the majority of pot sampling of this study, the immersion time was one day. However, this period was longer on some occasions either because of bad weather conditions or other commitments for R. V. Cuma. Since Hancock (1963) also stated that there was little change between catches of pots lifted after one day, and those left on the bottom for longer periods, as long as 7 days for the same species, catch pot ${ }^{-1}$ values were used in this study in order to estimate population density of Buccinum from pot sampling. However, although gear saturation was an important source of error in the estimation of population density of $B$. undatum in Hancock's study, I did not consider it as a serious problem, since pots were never observed to be completely full. This is perhaps because there is a much lower number (and biomass) of competing animals for the bait compared with Hancock's study. The distance between pots might be another reason, i.e. if there was a greater distance between pots in his study (there is no information on this), this might effect pot saturation. Each pot was approximately ten meters apart in the present study.

Except in March 1990, excessive amounts of scallops (Pecten maximus and Chlamys opercularis) and lesser spotted dogfish (Scyliorhinus canicula) or a combination of these were always used as bait during the pot sampling. It has been observed that scallops and dogfish were equally attractive as bait for Buccinum in comparison to herring and plaice (C. J. Gilling, pers. comm.). Therefore, the effects of bait used in this study on seasonal catches could be disregarded.

Fishing for whelks in the study area is certainly an important factor which would affect the seasonal catch. However, there was no commercial fishing in the sampling area, other than the collection of scallops using SCUBA diving by a few fishermen (personal communication with a local fisherman, B. Miles, Douglas, Isle of Man). The impracticability of fishing with dredges or trawls (due to high percentage of gravel, shell and stones) on this ground has been pointed out (C. J. Gilling, pers. comm.). Even if there was some fishing, the whelks would be returned to the sea together with other trash animals and materials as there is no market for them in this area due to a lack of demand. However, in this study there was a decrease in the catch during 1990 in comparison to the same months of 1989 at the beginning of sampling. This could be explained by consistent pot sampling causing a decrease in the common whelk population in the study area, as over 12000 whelks were removed from an approximate area of $0.13 \mathrm{~km}^{2}$ during the sampling period (approx. 0.1 indiv. or $0.4 \mathrm{~g} \mathrm{~m}^{-1}$ ). Similarly, the decrease from 762 tonnes in 1951 (where $7.47 \mathrm{~g} \mathrm{~m}^{-1}$ whelk removed from the fishing area) to below 100 tonnes in 1953 in the landings of whelks was suggested to be due to fishing on the east coast of England (Hancock, 1963).

There are several other factors which might affect catch levels of whelks (Hancock, 1963; Gros \& Santarelli, 1986; Martel et al. 1986b; Himmelman, 1988). These can be grouped as follows:

(a) biological factors; such as mating, spawning, feeding, recruitment, immigration and/or emigration.

(b) physical factors; such as ambient temperature and direction and speed of local currents. 
Immigration to or emigration from the defined population, would be an important factor which could affect the density estimation of whelks in this study. Whelks are generally slow-moving animals. For example, a comparatively bigger-size whelk Busycotypus canaliculatus can travel at $20 \mathrm{~cm} \mathrm{~min}^{-1}$ (Davis \& Sisson, 1988). Himmelman (1988) suggests that the common whelk may move at a maximum of $50 \mathrm{~m}^{\mathrm{day}}{ }^{-1}(-3 \mathrm{~cm}$ $\min ^{-1}$ ) in the field. A maximum crawling rate of $7 \mathrm{~cm} \mathrm{~min}^{-1}$ has been measured for the same species in the laboratory (C. J. Gilling, pers. comm.). However, the animal may spend a large proportion of its time quiescent, sometimes partially buried in bottom deposits (Hancock, 1963). With regard to the migration of common whelk, the most sound conclusion was probably drawn by Hancock (1963). In his study, he divided a total of 28 square miles of fishing area into 9 equal plots and carried out a comprehensive markrecapture study over a three-year period. From the recapture data, he observed that practically no mixing occurred between adjacent plots, which suggested that common whelk movements were very limited. A similar suggestion, as a result of mark-recapture study, was made for knobbed whelk, Busycon carica (Anderson et al., 1989). However, it should be noted that a limited movement in their habitat, particularly during copulation and egg-laying, may occur (Martel et al., 1986a, b). For example, during spawning, there is a tendency to come close inshore.

There was a decrease in the catch through the summer months when seawater temperatures were at their highest. This is consistent with Hancock's (1963) laboratory observation where the feeding rate was lowest in summer. He obtained the largest catches between April and May, in the field, on the east coast of England. However, in his study the largest catches occurred from late autumn to spring (only for 1989; unfortunately, there was no sampling in February and a smaller quantity of bait was used in March 1990). Martel et al. (1986a) studied the reproductive cycle and seasonal feeding activity of $B$. undatum in the Gulf of St Lawrence. They found that feeding activity was at a maximum in late autumn to early spring and decreased sharply in late May which is similar to the results in the present study. They suggested that the decrease in the feeding activity was caused by the onset of breeding in late spring. This is interesting, as the reproductive cycles of $B$. undatum in the Gulf of St Lawrence and off Douglas are quite different (see Kideys et al., 1992). In the Gulf of St Lawrence, egg-laying was in late May to July, whereas off the Isle of Man between December and January. Therefore, seasonal changes in catch (i.e. high in winter and low in summer) were probably due to (a) increased feeding activity in winter, probably to gain the energy which will be converted to egg capsules, and, (b) movement of whelks to the shore for copulation and spawning.

A knowledge of the area fished by pots is necessary to obtain absolute density of $B$. undatum in the study area. There are some studies on the attraction areas of pots for whelks. Using diving census methods, Davis \& Sisson (1988) estimated an attraction area of $3300 \mathrm{~m}^{2}$ per pot for channeled whelk Busycotypus canaliculatus in Nantucket Sound, Massachusetts. An attraction area of $1678 \mathrm{~m}^{2}$ was obtained for red whelk Neptunea arthritica using a mark-recapture method in Lagoon Huren-ko (Ito et al., 1981). These two whelks are much bigger than the common whelk. Himmelman (1988) used a markrecapture method to estimate the area of attraction of a pot for common whelk in the northern Gulf of St Lawrence. The range in attractant areas $\left(111-585 \mathrm{~m}^{2}\right)$, found under a current speed of $0.1-0.2 \mathrm{~m} \mathrm{~s}^{-1}$, was comparable with the value $\left(373 \mathrm{~m}^{2}\right)$ given for the Channel Isles region under $M_{2}$ tidal currents (max. speed $6 \mathrm{~m} \mathrm{~s}^{-1}$ ) for the same species 
(Gros \& Santarelli, 1986). Tidal currents to the southeast of the Isle of Man, which generally run along a NE-SW axis have a maximum speed of $0.93 \mathrm{~m} \mathrm{~s}^{-1}$ (Lyle, 1981). However, the study area is quite close to the shore (approximately $600-700 \mathrm{~m}$ ) and has much stronger tidal currents. Therefore, the value of $373 \mathrm{~m}^{2}$ from Gros \& Santarelli (1986) was assumed to be a reasonable estimate of the gathering area for a pot in this study.

The common whelk has been reported in the North Atlantic from low water mark to depths greater than $1000 \mathrm{~m}$ (Nielsen, 1975). It is interesting to note that densities measured in this study are similar to those from different regions for the same species using the same gear (namely pots). For example, a density of 0.40 ind. $\mathrm{m}^{-2}$ obtained in Channel Isles in May 1984 (Gros \& Santarelli, 1986) is similar to the density found here ( 0.33 ind $\mathrm{m}^{-2}$ ) for the same month. The range of densities found in this study for the summers 1989-1990 (0.08-0.20 ind. $\left.\mathrm{m}^{-2}\right)$ falls within those given for the Gulf of St Lawrence (0.05-0.24 ind. $\mathrm{m}^{-2}$; Himmelman, 1988) for summers of 1983-1984. This similarity in the density values among different regions may be related to the carrying capacity of similar grounds. However, relatively small Buccinum catches have been reported for some areas around the Isle of Man (C. J. Gilling, pers. comm.).

If we accept the idea that no substantial migrations occur, the relative decrease in catch rate through the sampling period does not explain the dramatic decrease in the recapture rate $7-8$ months after release. I do not think this was because of a greater vulnerability of tagged animals when compared to untagged animals. If vulnerability was affected, this would have been obvious just after release rather than months later. In the laboratory, it was found that tagging mortality was negligible when experimental conditions (especially space and seawater flow rate) were presumably optimal (see Kideys $_{i}$ 1991). Therefore, tagging mortality does not seem an important factor under field conditions. However, oxytetracycline, used as a marker in this study, which was observed not to cause acute mortality (Kideys, 1991), may affect the mortality rate of Buccinum over the long-term. If this is true, it could be the reason for the decrease in recaptures over time. Therefore, the density values estimated after a considerable interval following the release should be considered with caution. The density value of 0.49 individuals $\mathrm{m}^{-2}$ for June 1989 was obtained one month after release. The highest numbers of recaptures ( 8 individuals) were also observed in this month. There were no recaptures in July and August of 1989; the next recaptures ( 2 individuals) were in September and October of 1989. These gave density values of 0.99 and 1.26 individuals $\mathrm{m}^{-2}$, respectively. Clearly, there is a substantial difference between the density estimates obtained from markrecapture and from pot sampling. The inefficiency of mark-recapture method in the density estimation of this species has been reported in a recent investigation (SainteMarie, 1991).

Three main advantages of underwater television survey over diving are: (a) the former can cover larger areas than divers; (b) it can be operated in deeper water and for longer periods; and (c) it also provides a vast amount of background information, including the general structure of bottom type, which can be studied in detail later from tapes. Depending on the bottom structure of the area and on the size of animals studied, this method can yield very useful information on population abundance (Franklin et al., 1980; Bergstrom et al., 1987). However, an overestimation of the density of Buccinum from underwater television survey was possible, because dead Buccinum or other shells could have been included in the survey counts of live Buccinum. I suggest this is the 
reason for a high overall density estimate $\left(0.33\right.$ individuals $\mathrm{m}^{-2}$ for whelks $>60 \mathrm{~mm}$ in length) obtained from an underwater video survey in September 1991. This result is somewhat higher than those from pot sampling and diving.

The SCUBA diving technique, with an area-representative sampling strategy, is a relatively reliable method for estimating population density estimation of many shellfishes (Mason et al., 1982). Perhaps this is the reason why it has been utilized to measure the efficiency of the gear (i.e. dredge, trawl, pot, grab etc.) used for fishing the animal (Allen \& Cranfield, 1979; Davis \& Sisson, 1988). The mean value of 0.17 individuals $\mathrm{m}^{-2}$ obtained from a diving survey in June 1990 shows very good agreement with an estimate of 0.18 individuals $\mathrm{m}^{-2}$ from pot sampling for the same month (Table 4). The finding is that the results obtained from SCUBA diving corroborate results from pot sampling. Thus, it can be suggested that when a good estimate of pot attraction area is at hand, pot sampling can be used in the determination of the density of $B$. undatum particularly where the direct census of whelks is difficult due to logistic problems.

Table 4. Comparison of density results using different methods

\begin{tabular}{|lcc|}
\hline \multicolumn{1}{|c}{ Method } & Month & Density (ind. $\mathrm{m}^{-2}$ ) \\
\hline Mark-recapture & June 89 & 0.49 \\
Pot sampling & June 89 & 0.18 \\
Pot sampling & June 90 & 0.19 \\
Diving & June 90 & 0.16 \\
Pot sampling & Sept. 89 & 0.14 \\
Underwater television & Sept. 90 & 0.33 \\
\hline
\end{tabular}

Acknowledgements. This study was carried out while the author was sponsored by the Institute of Marine Sciences of Middle East Technical University (IMS-METU) of Turkey. The helpful comments of Dr. R. D. M. Nash during the preparation of the early drafts of the manuscript are gratefully acknowledged.

\section{LITERATURE CITED}

Allen, R. L. \& Cranfield, H. J., 1979. A dredge survey of the oyster population in Foveaux Strait. Rapp. P.-v. Réun. Cons. int. Explor. Mer, 175, 50-63.

Anderson, B. A., Eversole, A. G. \& Anderson, W. D., 1989. Variations in shell and radula morphologies of knobbed whelks. - J. Shellfish Res. 8, 213-218.

Bennett, D. B., 1974. The effects of pot immersion time on catches of crabs Cancer pagurus L. and lobsters Homarus gammarus (L.). - J. Cons. int. Explor. Mer. 35, 332-336.

Bennett, D. B. \& Brown, C. G., 1979. The problems of pot immersion time in recording and analysing catch-effort data from a trap fishery. - Rapp. P.-v. Réun. Cons. int. Explor. Mer. 175, 186-190.

Bennett, D. B. \& Lovewell, S. R. J., 1977. The effects of pot immersion time on catches of lobsters Homarus gammarus (L.) in the Welsh coast fishery. - Fish. Res. tech. Rep. 36, $1-4$.

Bergstrom Bo, I., Larsson, J. \& Pettersson, J.-O., 1987. Use of a remotely operated vehicle (ROV) to study marine phenomena: I. Pandalid shrimp densities. - Mar. Ecol. Prog. Ser. 37, 97-101.

Chapman, C. J., Mason, J. \& Kinnear, J. A. M., 1977. Diving observations on the efficiency of dredges used in the Scottish fishery for the scallop, Pecten maximus (L.). - Scott. Fish. Res. Rep. $10,1-16$.

Davis, J. P. \& Sisson, R. T., 1988. Aspects of the biology relating to the fisheries management of New 
England populations of the whelks, Busycotypus canaliculatus and Busycon carica. - J. Shellfish Res. 7, 453-460.

Franklin, A., Pickett, G. D., Holme, N. A. \& Barrett, R. L., 1980. Surveying stocks of scallops (Pecten maximus) and queens (Chlamys opercularis) with underwater television. - J. mar. biol. Ass. U. K. 60, 181-191.

Forster, G. R., 1967. The growth of Haliotis tuberculata. Results of tagging experiments in Guernsey. J. mar. biol. Ass. U. K. 47, 287-300.

Gros, P. \& Santarelli, L., 1986. Méthode d'estimation de la surface de pêche d'un casier à l'aide d'une filière expérimentale. - Oceanologica Acta 9, 81-87.

Hancock, D. A., 1963. Marking experiments with the commercial whelk (Buccinum undatum). Spec. Publs. int. Commn. NW. Atlant. Fish. 4, 176-187.

Himmelman, J. H., 1988. Movement of whelks (Buccinum undatum) towards a baited trap. - Mar. Biol. 97, 521-531.

Holme, N. A. \& Barrett, L., 1977. A sledge with television and photographic cameras for quantitative investigation of the epifauna on the continental shelf. - J. mar. biol. Ass. U. K. 57, 391-403.

Ito, H. \& Tachizawa, S., 1981. An estimation of the available stock of a snail, Neptunea arthritica, by trap fishing. - Bull. Hokkaido reg. Fish. Res. Lab. 46, 113-119.

Ito, H., Wakui, T. \& Domon, Y., 1980. Methods for marking sea snails, genus Buccinum - Bull. Hokkaido reg. Fish. Res. Lab. 45, 65-74.

Ito, H., Wakui, T., Tateuchi, Y. \& Tachizawa, S., 1981. Observations on the behaviour of a sea snail, Neptunea arthritica, toward a trap. - Bull. Hokkaido reg. Fish. Res. Lab. 46, 97-111.

Jones, R., 1976. The use of marking data in fish population analysis. - F. A. O. Fish. tech. Pap. 153, $1-42$.

Kennelly, S. J., 1989. Effect of soak-time and spatial heterogeneity on sampling populations of spanner crabs Ranina ranina. - Mar. Ecol. Prog. Ser. 55, 141-147.

Kideys, A. E., 1991. The ecology of the common whelk Buccinum undatum. L. off Douglas, Isle of Man, with special reference to its ecological energetics. - Thesis, Univ. of Liverpool, $161 \mathrm{pp}$.

Kideys, A. E. \& Hartnoll, R. G., 1991. Energetics of mucus production in the common whelk Buccinum undatum L. - J. exp. mar. Biol. Ecol. 150, 91-105.

Kideys, A. E., Hartnoll, R. G. \& Nash, R. D. M., 1992. Reproductive cycle and energetic cost of reproduction of the neogastropod Buccinum undatum L. in the Irish Sea. - J. mar. biol. Ass. U. K. (In press).

Kraeuter, J. N., Castagna, M. \& Bisker, R., 1989. Growth rate estimates for Busycon carica (Gmelin, 1791 ) in Virginia. - J. Shellfish Res. 8, 219-225.

Lyle, J. M., 1981. Feeding, utilization of food and growth in the lesser spotted dogfish Scyliorhinus canicula (L.) from Isle of Man waters. - Thesis, Univ. of Liverpool, $152 \mathrm{pp}$.

Machan, R. \& Fedra, K., 1975. A new towed underwater camera system for wide-range benthic surveys. - Mar. Biol. 33, 75-84.

MacIntosh, R. A., 1980. The snail resource of the Bering Sea and its fishery, - Mar. Fish. Rev. 42, 15-20.

Martel, A., Larrivee, D. H. \& Himmelman, J. H., 1986a. Behaviour and timing of copulation and egglaying in the neogastropod Buccinum undatum L.-J. exp. mar. Biol. Ecol. 96, 27-42.

Martel, A., Larrivee, D. H., Klein, K. R. \& Himmelman, J, H., 1986b. Reproductive cycle and feeding activity of the neogastropod Buccinum undatum L. - Mar. Biol. 92, 211-221.

Mason, J., Drinkwater, J., Howell, T. R. W. \& Fraser, D. I., 1982. A comparison of methods of determining the distribution and density of the scallop, Pecten maximus (L.) - C. M./ICES K 24, $1-5$.

Miller, R. J., 1975. Density of the commercial spider crab, Chionoecetes opilio, and calibration of effective area fished per trap using bottom photography. - J. Fish. Res. Bd Can. 32, 761-768.

Murphy, E. J., 1986. An investigation of the population dynamics of the exploited scallop, Pecten maximus (L.) in the North Irish Sea. - Thesis, Univ. of Liverpool, $155 \mathrm{pp}$.

Nielsen, C., 1975. Observations on Buccinum undatum L. attacking bivalves and on prey responses, with a short review on attack methods of other prosobranchs. - Ophelia 13, 87-108.

Peck, L. S., Culley, M. B. \&. Helm, M. M., 1990. Structure and density of Haliotis tuberculata populations around the coasts of Jersey, Channel Isles. - J. mar. biol. Ass. U. K. 70, 67-75. 
Ricker, W. E., 1975. Computation and interpretation of biological statistics of fish populations. - Bull. Fish. Res. Bd Can. 191, 1-300.

Sainte-Marie, B., 1991. Whelk (Buccinum undatum) movement and its implications for the use of tag-recapture methods for the determination of baited trap fishing parameters. - Can. J. Fish. aquat. Sci. $48,751-756$.

Santarelli, L. \& Gros, P., 1985. Determination de l'âge et de la croissance de Buccinum undatum L. (Gastropoda: Prosobranchia) à l'aide des isotopes stables de la coquille et de l'ornementation operculaire. - Oceanologica Acta 8, 221-229.

Sire, J-V., 1984. Vital staining technique in the study of the shell and calcified operculum's growth of the polynesian gastropod, Turbo setosus Gmelin (Prosobranches, Turbinidae). - Bull. Soc. zool. Fr. 109, 99-112.

Skud, B. E., 1979. Soak time and the catch per pot in an offshore fishery for lobsters (Homarus americanus). - Rapp. P.-v. Réun. Cons. int. Explor. Mer. 175, 190-196. 